\title{
$\mathrm{SDS}$ 계면활성제 첨가에 따른 14 캐럿 백색 금합금의 티오우레아 스트리핑의 효과
}

김익규 · 김광배 · 송오성*

서울시립대학교 신소재공학과

\section{Effects of Thiourea Stripping of 14 Karat White Gold Alloys With the Addition of SDS Surfactant}

\author{
Ikgyu Kim, Kwangbae Kim, and Ohsung Song* \\ Department of Materials Science and Engineering, University of Seoul, Seoul 02504, Republic of Korea
}

\begin{abstract}
A stripping solution with thiourea, iron(III) sulfate, and sodium dodecyl sulfate(SDS) was employed to strip Ni-based 14 karat white gold alloys, and the formation of the NiS byproduct and elimination of passivation were investigated in the presence of 0.0-0.2 g/L SDS. White gold alloy samples with a flat shape were cast by gypsum investment and were stripped using the prepared stripping solution. Subsequently, the surface morphology, elimination of the passivation layer, weight loss, microstructure, elemental composition, and electrochemical properties of the samples were analyzed by optical microscopy, Raman spectroscopy, precision scale, scanning electron microscopy, energy dispersive X-ray spectroscopy, and linear sweep voltammetry, respectively. It was found that passivation layers of the as-cast samples were removed by the suggested stripping solution. Upon the addition of SDS, the stripped sample showed a bright silver color without NiS, while the sample showed a dark tarnished appearance due to NiS formation without SDS. The weight loss ratio decreased with increasing SDS content and stabilized at $0.2 \%$ for SDS concentrations exceeding $0.15 \mathrm{~g} / \mathrm{L}$, and the sample showed a uniformly etched microstructure. EDS results showed that NiS was formed without SDS addition, while linear sweep voltammetry results indicated that NiS formation was restrained upon SDS addition because SDS suppresses the formation of formamidine disulfide from thiourea. Thus, the suggested thiourea stripping with SDS addition was successfully applied to Ni-based 14 karat white gold alloys.
\end{abstract}

(Received March 3, 2020; Accepted May 23, 2020)

Keywords: 14 karat white gold alloy, sodium dodecyl sulfate, thiourea stripping, passivation

\section{1. 서 론}

일반적으로 금합금을 이용한 장신구는 인베스트먼트 주 조법으로 제조되며, 주조된 제품 표면의 부동태막을 화학 적으로 제거한 후, 기계적인 연마 공정을 거쳐 완성된다. 표면 부동태막을 제거해 광택을 향상시키는 공정을 스트리 핑(stripping)이라고 하며, 최근까지 이 공정에 시아나이드 용액이 사용되고 있다 [1].

- 김익규: 석사과정, 김광배: 박사과정, 송오성: 교수

*Corresponding Author: Ohsung Song

[Tel: +82-2-6490-5780, E-mail: songos@uos.ac.kr]

Copyright (C) The Korean Institute of Metals and Materials
시아나이드 스트리핑(cyanide stripping)은 과산화수소 (hydrogen peroxide)를 산화제, 시안화나트륨(sodium cyanide)이나 시안화칼슘(potassium cyanide)을 착물제로 첨가한 용액을 $90{ }^{\circ} \mathrm{C}$ 이상으로 가열 후, 주조된 금합금을 침지시키는 것이다 [2]. 이러한 시아나이드 공정은 $\mathrm{Au}-\mathrm{Cu}$ 계 노란색 및 적색 금합금 그리고 $\mathrm{Au}-\mathrm{Ni}$ 계 백색 금합금을 $14 \mathrm{~K}, 18 \mathrm{~K}$ 등 종류에 상관없이 동시에 처리가 가능한 범 용성을 가지고 있다. 또한 저렴한 공정비용과 단시간 처리 가 가능하고, 용출된 $\mathrm{Au}$ 의 회수율이 높은 장점으로 많은 국가에서 이용하고 있다. 그러나 시아나이드 용액의 자체 위험성과 공정 후 환경적인 문제로 이미 유럽 등의 선진국 에서는 사용이 금지되었고, 이를 대체하기 위한 연구가 활 
발하다.

기존 시아나이드 스트리핑 대체 공정으로는 할라이드 스 트리핑(halide stripping)과 티올 화합물 스트리핑(thiol compound stripping) 방법이 제안되었다. 이러한 방법들도 시아나이드 스트리핑과 유사하게 산화제와 착물제로 구성 된 스트리핑 용액으로 주조직후 금합금의 부동태막을 제거 한다 [3]. 할라이드 스트리핑은 착물제로 할로겐(halogen) 화합물을 사용하는 방법으로, 할로겐 화합물로부터 생성된 할로겐 이온이 금속 착물을 형성한다. Baghalha 등[4]은 하이포아염소산(hypochlorite)을 산화제, 염화소듬(sodium chloride)을 착물제로 채용하여 최적 조건에서는 기존 시아 나이드 스트리핑 보다 반응속도가 빠른 장점을 보고하였으 나, 공정 중 유독한 염소가스가 방출되는 문제가 있었다 [5]. Seisko 등[6]은 유독가스가 방출되는 문제를 해결하기 위해 $\mathrm{Fe}^{3+}$ 와 $\mathrm{Cu}^{2+}$ 산화제, 염화소듐을 착물제로 채용하였 으나, $95{ }^{\circ} \mathrm{C}$ 에서 순수한 $\mathrm{Au}$ 의 스트리핑 속도가 기존 시아 나이드 공정에 비해 $1 / 10$ 로 감소하는 문제가 있었다 [7]. 따라서 할라이드 스트리핑은 유독가스발생과 공정시간의 증가로 시아나이드를 대체하는데 한계가 있다.

티올 화합물 스트리핑은 착물제로 티오황산(thiosulfate), 티오우레아(thiourea) 같은 화합물을 채용한 것으로, $\mathrm{Au}$ 이 온과 강한 착물을 형성한다. 티오황산을 이용한 방법으로 Muir 등[8]이 $\mathrm{Cu}^{2+}$ 산화제, 티오황산염을 착물제로 채용한 공정을 보고하였으며, 이 공정은 수소이온농도 $(\mathrm{pH})$ 6-10의 조건에서 반응하여 비교적 안전하다. 그러나 순수한 $\mathrm{Au}$ 의 경우 용출속도가 기존 시아나이드 스트리핑의 $1 / 5$ 정도로 느려서 실제 공정으로 적용하는데 한계가 있었다 [9].

티오우레아를 사용하는 방법으로 $\mathrm{Li}$ 등[10]이 $\mathrm{Au}$ 도금 된 전자제품에서 $\mathrm{Au}$ 를 추출하는데, $\mathrm{Fe}^{3+}$ 산화제, 티오우레 아를 착물제로 채용한 공정을 보고한 바 있다. 이 공정은 유독가스가 발생하지 않으며, 최적 조건인 $\mathrm{pH}$ 2에서는 시 아나이드 스트리핑보다 반응속도가 빨라서, 시아나이드 스 트리핑을 대체할 수 있는 가능성을 보였다.

그러나 티오우레아를 사용한 스트리핑 공정의 경우, 금 속에 함유된 성분에 따라 금속황화물이 형성되는 문제가 보고된 바 있으며, So 등[11]이 $\mathrm{Ag}$ 도금된 전자제품의 티 오우레아를 이용한 스트리핑 공정에서 $\mathrm{Ag}$ 황화물이 생성 되는 문제를 보고하였다. 또한 $\mathrm{Lin}$ 등[12]은 $\mathrm{Au}-\mathrm{Ni}-\mathrm{Cu}$ 도 금층을 티오우레아로 스트리핑하는 과정에서 검은색의 금 속황화물이 형성되는 문제를, Mohanty 등[13]은 티오우레 아를 이용한 $\mathrm{Ni}$ 전기도금실험에서 전극부분에 치밀한 $\mathrm{NiS}$ 가 형성되는 문제를 확인한 바 있다.

이러한 금속황화물 생성을 방지하기 위해 여러 가지 유
기계면활성제를 채용한 연구가 보고되고 있다. Feng 등 [14]은 저품위 금원광(gold ore)을 티오황산 용액으로 스트 리핑 시, 카복시메틸 셀룰로오스(carboxymethyl cellulose) 계면활성제를 첨가하여 금속황화물의 형성을 억제할 수 있 다고 보고하였다. Dutta 등[15]은 티오우레아와 구리이온의 반응에서 $\mathrm{SDS}$ 를 채용하여 금속황화물의 침전을 억제하였 다. 그러나 티오황산은 반응속도가 느린 문제를, 티오우레 아의 경우 $\mathrm{Ni}$ 이 포함된 합금에서 금속황화물이 생성되는 문제를 해결하지 못 했다.

이와 같이 티오우레아 스트리핑은 우수한 반응속도로 인 해 기존 시아나이드 스트리핑을 대체하는 여러 방안으로 가장 유력하다. 특히 $\mathrm{Ni}$ 계-백색 금합금에 적용될 때 흑색 니켈황화물이 생성되는 문제만 해결된다면 시아나이드 스 트리핑과 같이 노란색, 적색 금합금은 물론이고 백색 금합 금까지 범용적으로 사용될 수 있다.

본 연구에서는 $\mathrm{Ni}$ 계-14K 백색 금합금에 대한 티오우레 아 스트리핑의 적용 가능성을 확인하기 위해, 계면활성제 인 SDS의 함량을 달리하며 니켈황화물 생성 없이 스트리 핑 가능한 조건을 확인하였다.

\section{2. 실험방법}

석고몰드를 이용한 인베스트먼트 주조법으로 제작된 가 로, 세로, 높이가 각각 $5 \mathrm{~mm}, 5 \mathrm{~mm}, 1 \mathrm{~mm}$ 인 장방형 $\mathrm{Ni}$ 계 $-14 \mathrm{~K}$ 백색 금합금을 제작하였다. 이때 금합금의 조성은 $\mathrm{Cu}$ 29.05, $\mathrm{Zn} 7.05, \mathrm{Ni} 5.40, \mathrm{Au} 58.50 \mathrm{wt} \%$ 가 되도록 준비하여, $\mathrm{Ni}$ 이 백색 금합금의 주요발색원소가 되도록 하 였다.

표 1에는 SDS 함량을 달리하여 제작한 스트리핑 용액의 조성을 나타내었으며, $\mathrm{pH}$ 는 황산을 이용하여 2로 조절하 였다. 준비된 용액 $20 \mathrm{ml}$ 에 $14 \mathrm{~K}$ 백색 금합금을 침지하고 $50{ }^{\circ} \mathrm{C}$ 에서 5 분 초음파 교반 후 $28 \%$ 과산화수소 수용액 $3 \mathrm{ml}$ 를 첨가하고 1 분간 추가로 교반하였다.

스트리핑 전후 육안 변화는 광학현미경(815000, GIA Instrument Co.)을 이용하였다. 부동태막의 변화는 라만분

Table 1. Chemical composition of thiourea stripping solution with SDS.

\begin{tabular}{ccc}
\hline Function & Composition & Concentration $(\mathrm{g} / \mathrm{L})$ \\
\hline Complex agent & Thiourea & 12 \\
Oxidant & Iron(III)sulfate & 6 \\
Surfactant & $\begin{array}{c}\text { Sodium dodecyl } \\
\text { sulfate (SDS) }\end{array}$ & $0,0.05,0.1,0.15,0.20$ \\
\hline
\end{tabular}


광기(UniRaman, Unithink)를 사용하여 확인하였으며, 이때 광원은 $531 \mathrm{~nm}$ 을 채용하고, 30 초 동안 노광하여 10 회 반복 측정하였다.

$\mathrm{SDS}$ 함량에 따른 스트리핑 후 합금의 무게변화는 정밀저 울(AS60/220/C/2, Radwag)을 이용하여 $1.0 \times 10^{-5} \mathrm{~g}$ 까지의 무게 변화를 측정하였다. 무게감소율은 스트리핑 전후 합 금의 무게변화를 백분율로 계산하였다.

스트리핑 전후 미세구조 변화와 원소 조성은 주사형전자 현미경(FE-SEM, S-4300, Hitachi)과 에너지분산X선분광기 (EDS, JSM-6010PLUS/LA, Jeol)를 이용하여 분석하였다.

$\mathrm{SDS}$ 함량에 따른 전기화학적 특성은 상온에서 3 극 전기 화학셀(Digi-Ivy, Austin TX)을 이용하여 선형주사전압법 (liner sweep voltammetry, LSV)으로 분석하였다. 이때 $\mathrm{Ag} / \mathrm{AgCl}$ 전극, 백금와이어, $14 \mathrm{~K}$ 백색 금합금 시편을 각 각 기준전극, 상대전극, 작업전극으로 사용했으며, 전해질은 표 1 의 조성과 동일하게 준비하였다. 준비된 시편의 작업 전극은 $-0.2 \mathrm{~V}$ 부터 $+0.8 \mathrm{~V}$ 까지 전위(potential)를 $1 \mathrm{mV} / \mathrm{s}$ 로 속도로 인가시키면서 산화전류밀도를 측정하였다.

\section{3. 결과 및 고찰}

그림 1은 스트리핑 전과 스트리핑 후 $\mathrm{SDS}$ 함량에 따른 시편의 육안 분석 이미지이다. 그림 1 (a)는 주조 직후 시 편의 이미지로, 광택이 없는 어두운 회색 표면을 확인하였 다. 그림 1 (b)는 $\mathrm{SDS}$ 가 첨가되지 않은 스트리핑 용액으 로 처리한 시편 이미지이며, 표면에 검은색 막이 형성되었 다. 이러한 현상은 Mohanty 등[13]이 보고한 티오우레아와 $\mathrm{Ni}$ 이 반응하여 치밀한 검은 피막을 형성한다는 결과와 일 치하였다.

그림 1 (c), (d), (e), (f)에는 각각 $\mathrm{SDS}$ 가 0.05, 0.10, $0.15,0.20 \mathrm{~g} / \mathrm{L}$ 첨가된 용액으로 스트리핑 한 결과를 나타 내었다. 그림 1 (c)에 나타낸 $\mathrm{SDS} 0.05 \mathrm{~g} / \mathrm{L}$ 첨가한 경우 는 표면이 다소 어두웠으나, $\operatorname{SDS}$ 함량이 (d)와 같이 0.10 $\mathrm{g} / \mathrm{L}$ 로 증가하면 백색감과 광택감이 증가하고, $\mathrm{SDS}$ 가 0.15 $\mathrm{g} / \mathrm{L}$ 이상 첨가되는 경우 (e), (f)와 같이 표면 전체가 광택 이 있는 은백색으로 나타났다. 즉, 티오우레아 스트리핑 공 정에 $\mathrm{SDS}$ 첨가량이 증가함에 따라 검은 부산물의 형성이 억제되었다.

그림 2는 주조 직후와 스트리핑 후 $14 \mathrm{~K}$ 백색 금합금 시편의 라만 분석결과이다. 상단부터 스트리핑 전, $\mathrm{SDS}$ 가 첨가되지 않은 용액, 그리고 $\mathrm{SDS}$ 가 $0.10,0.20 \mathrm{~g} / \mathrm{L}$ 첨가된 용액으로 스트리핑 한 시편의 라만 결과를 나타내었다.

주조직후에는 강한 $\mathrm{CuS}$ 피크가 확인되었으며, 이는 Ingo

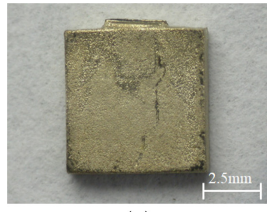

(a)

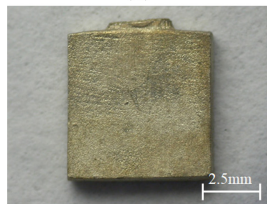

(d)

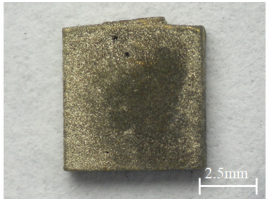

(b)

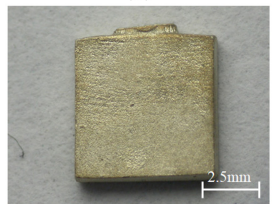

(e)

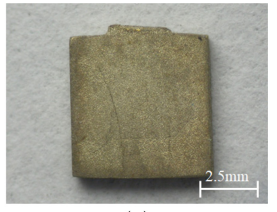

(c)

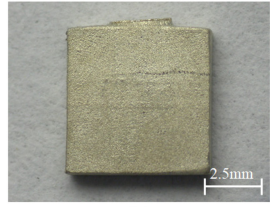

(f)
Fig. 1. Optical images of $14 \mathrm{~K}$ WG; (a) as-casted sample, and stripped samples with SDS of (b) 0.0, (c) 0.05, (d) 0.10, (e) 0.15, (f) $0.20 \mathrm{~g} / \mathrm{L}$.

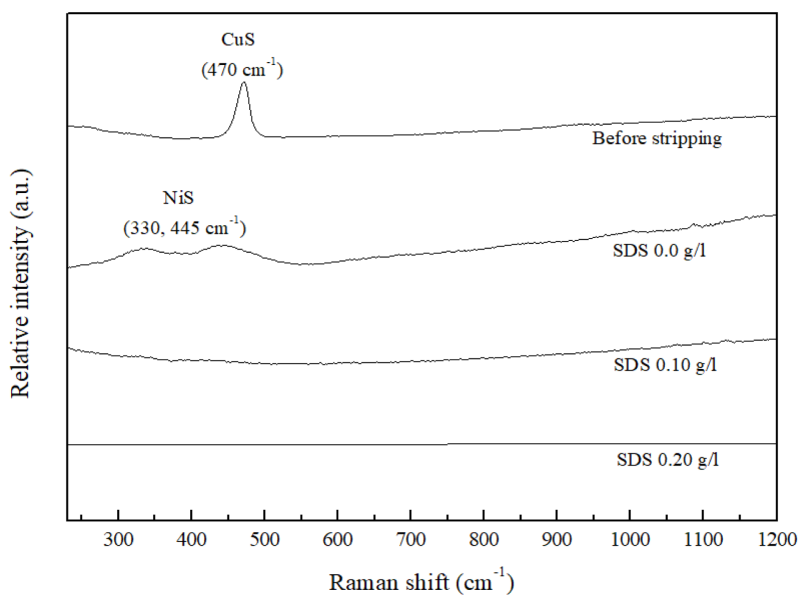

Fig. 2. Raman results according to SDS contents.

등[16]이 보고한 바와 같이 환원포텐셜(reduction potential) 이 낮은 $\mathrm{Cu}$ 가 주조과정 중 산화되면서 표면부에 부동태막 을 형성한다는 보고와 일치하였다. SDS가 첨가되지 않은 스트리핑 용액으로 처리한 시편의 경우, $\mathrm{CuS}$ 피크는 확인 되지 않았고, $\mathrm{NiS}$ 피크만 확인되었다. 즉, 스트리핑을 통해 주조직후의 $\mathrm{CuS}$ 부동태막은 제거되었지만, 새로운 $\mathrm{NiS}$ 부 산물막이 생성되었다. 이는 앞서 그림 1 (b)에서 확인한 검은색 막이 $\mathrm{NiS}$ 라는 것을 의미하며, 이러한 현상은 티오 우레아의 자기분해로 생성된 황화물이 금합금 표면에 용출 된 $\mathrm{Ni}$ 이온과 반응하기 때문이다 [17].

$\mathrm{SDS} 0.10,0.20 \mathrm{~g} / \mathrm{L}$ 첨가된 용액으로 스트리핑된 시편에 는 $\mathrm{CuS}, \mathrm{NiS}$ 모두 나타나지 않았다. 이는 $\mathrm{SDS}$ 의 참가가 $\mathrm{CuS}$ 부동태막 제거에는 영향을 미치지 않으며, $\mathrm{NiS}$ 피막 형성을 억제하는 것을 의미한다.

그림 3에는 $\mathrm{SDS}$ 함량에 따른 $14 \mathrm{~K}$ 백색 금합금 시료의 무게감소율을 나타내었다. SDS를 첨가하지 않는 경우 무 


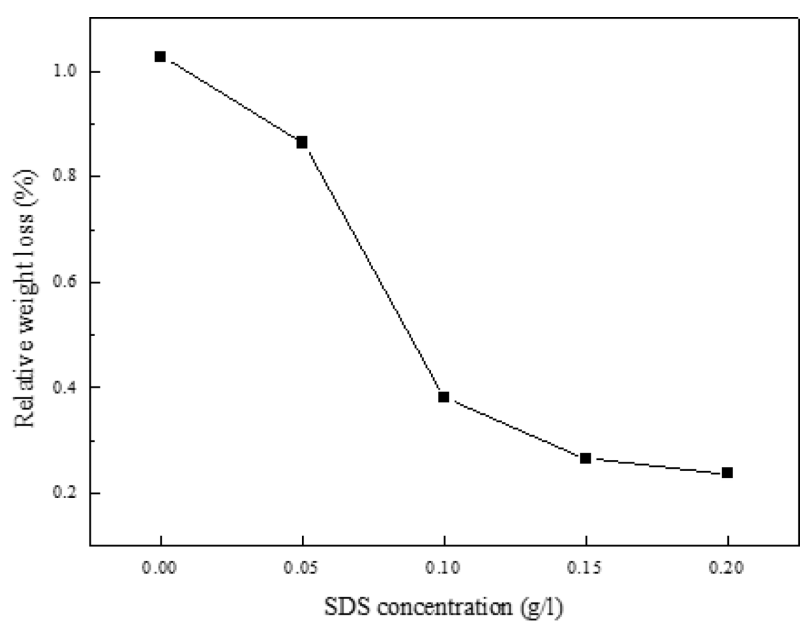

Fig. 3. Weight loss according to SDS contents.

게감소율은 $1.1 \%$ 로 나타났으나, SDS 함량이 증가함에 따 라 무게감소율이 작아지다가 $\operatorname{SDS} 0.15 \mathrm{~g} / \mathrm{L}$ 이후 약 $0.2 \%$ 로 수렴하였다. 이러한 결과는 음이온성 계면활성제인 $\mathrm{SDS}$ 가 합금의 표면에 흡착되어 스트리핑에 의한 백색 금합금 과 산화제간 레독스 반응을 차단하기 때문으로 판단하였으 며, 이는 Soares 등[18]이 보고한 바와 일치하였다.

따라서 Ni계-14K 백색 금합금의 스트리핑 시 $0.15 \mathrm{~g} / \mathrm{L}$ 이상 첨가하는 것이 부동태막의 제거와 무게감소율 면에서 바람직하였다.

또한, 실제 장신구 제품의 생산과정에서 스트리핑으로 인 한 금합금의 무게감소가 증가하게 되면 용출되는 금의 양 도 증가되어 경제적으로 불리하지만, $\mathrm{SDS}$ 가 첨가된 스트 리핑 공정에서는 중량 손실을 $1 / 5$ 로 줄일 수 있어 경제적 으로 유리한 공정임을 확인하였다 [19].

그림 4 에는 주조직후와 스트리핑 후의 $14 \mathrm{~K}$ 백색 금합 금 시편의 미세구조를 나타내었다. 그림 4 (a)는 주조직후 시편 표면의 SEM 이미지로, P1으로 표시한 밝은 부분과 $\mathrm{P} 2$ 로 표시한 어두운 부분이 존재하는 미세구조를 확인하였 다. 이는 그림 2에서 확인한 상대적으로 전기 전도도가 낮 은 $\mathrm{CuS}$ 로 인해 나타난 미세구조이다. 그림 4 (b)에는 $\mathrm{SDS}$ 가 첨가되지 않은 용액으로 스트리핑한 시편의 SEM 이미지를 나타내었다. 주조직후 시편에 비해 평탄해진 표 면을 확인할 수 있으며, P3로 표시한 아일랜드상(island phase)과 $\mathrm{P} 4$ 로 표시한 상대적으로 어두운 부분이 있었다. $\mathrm{P} 3$ 와 같은 아일랜드 부분은 스트리핑 과정에서 합금의 상 에 따라 에칭 정도가 상이하여 나타난 결과였으며, $\mathrm{P} 4$ 와 같은 상대적으로 어두운 부분은 앞서 그림 2에서 확인한 바와 같이 스트리핑 과정에서 형성된 $\mathrm{NiS}$ 부동태막 때문

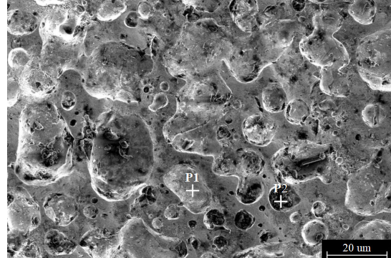

(a)

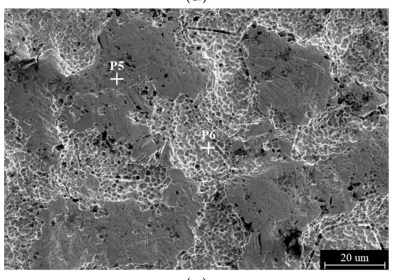

(c)

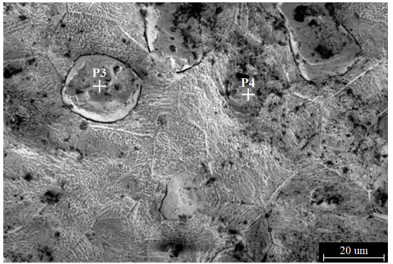

(b)

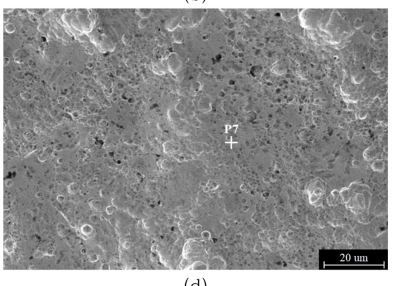

(d)
Fig. 4. SEM images of $14 \mathrm{~K} \mathrm{WG}$; (a) as-casted sample, and stripped samples with SDS of (b) 0.0 , (c) 0.1 , (d) $0.2 \mathrm{~g} / \mathrm{L}$.

에 나타난 것이다. 이러한 부동태막의 형성은 그림 1 에서 확인한 검은색 물질의 형성과도 일치하는 결과였다. 그림 4 (c)는 $\mathrm{SDS} 0.1 \mathrm{~g} / \mathrm{L}$ 첨가한 용액으로 스트리핑한 시편의 $\mathrm{SEM}$ 이미지이며, $\mathrm{P} 5$ 로 표시한 평탄부와 $\mathrm{P} 6$ 으로 표시한 에칭부가 존재하였고, $\mathrm{SDS}$ 가 첨가됨에 따라 스트리핑 과 정에서 표면 에칭에도 영향을 미쳐 균일한 상을 갖는 미세 구조를 보였다. 이러한 $\mathrm{SDS}$ 의 첨가에 따른 에칭속도는 그 림 3에서 확인한 무게감소율을 통해 확인할 수 있었다. 그 림 4 (d)는 SDS $0.2 \mathrm{~g} / \mathrm{L}$ 첨가한 용액으로 스트리핑한 시편 의 $\mathrm{SEM}$ 이미지이며, $\mathrm{P} 7$ 로 표시한 바와 같이 평탄부와 에 칭부 구별이 없이 모두 평탄한 표면을 보였다. 이는 SDS의 첨가로 인해 과도한 에칭이 억제되어 나타난 것이다.

따라서 SDS 첨가량이 증가함에 따라 표면의 과도한 에 칭을 억제하기 때문에 금합금 시료의 무게감소율은 감소하 였다. 결국 $\mathrm{SDS}$ 가 $0.15 \mathrm{~g} / \mathrm{L}$ 이상으로 첨가된 조건에서 과 도한 표면에칭 없이 무게감소율이 낮으면서도, 광택이 있 는 표면처리가 가능하였다.

표 2에는 그림 4에 표시된 P1 P7 부분의 $\mathrm{Au}, \mathrm{Cu}, \mathrm{Ni}$, $\mathrm{Zn}$ 및 $\mathrm{S}$ 원소의 $\mathrm{EDS}$ 분석결과를 나타내었다. 주조직후 시편에서의 명암차이가 보였던 $\mathrm{P} 1$ 과 $\mathrm{P} 2$ 에서, $\mathrm{P} 1$ 의 원소함 량은 $57.02 \mathrm{wt} \% \mathrm{Au}, 31.75 \mathrm{wt} \% \mathrm{Cu}, 4.38 \mathrm{wt} \% \mathrm{Ni}, 6.72$ $\mathrm{wt} \% \mathrm{Zn}, 0.13 \mathrm{wt} \% \mathrm{~S}$ 이며, P2의 원소는 $4.64 \mathrm{wt} \% \mathrm{Au}$, $71.41 \mathrm{wt} \% \mathrm{Cu}, 7.93 \mathrm{wt} \% \mathrm{Ni}, 15.88 \mathrm{wt} \% \mathrm{Zn}, 0.14 \mathrm{wt} \%$ $\mathrm{S}$ 이었다. 이때 $\mathrm{P} 1$ 과 $\mathrm{P} 2$ 에서 검출된 $\mathrm{S}$ 는 그림 2 라만분석 결과에서 확인한 주조과정에서 형성된 $\mathrm{CuS}$ 부동태막 때문 으로, $\mathrm{P} 1$ 과 $\mathrm{P} 2$ 의 명암차는 $\mathrm{CuS}$ 부동태막의 두께 차이로 나타난 현상으로 판단하였다.

$\mathrm{SDS}$ 의 첨가가 없는 $\mathrm{P} 3$ 와 $\mathrm{P} 4$ 는 각각 $99.89 \mathrm{wt} \% \mathrm{Au}$ 와 
Table 2. EDS results of points indicated in Fig. 4.

\begin{tabular}{|c|c|c|c|c|c|}
\hline Point & $\mathrm{Au}$ & $\mathrm{Cu}$ & $\mathrm{Ni}$ & $\mathrm{Zn}$ & $\mathrm{S}$ \\
\hline P1 & 57.02 & 31.75 & 4.38 & 6.72 & 0.13 \\
\hline $\mathrm{P} 2$ & 4.64 & 71.41 & 7.93 & 15.88 & 0.14 \\
\hline P3 & 99.89 & - & - & - & 0.11 \\
\hline P4 & 50.96 & 35.26 & 6.04 & 7.32 & 0.42 \\
\hline P5 & 57.81 & 30.81 & 5.85 & 5.53 & - \\
\hline P6 & 54.97 & 33.77 & 5.91 & 5.39 & - \\
\hline P7 & 57.74 & 30.88 & 5.29 & 6.09 & - \\
\hline
\end{tabular}

$0.11 \mathrm{wt} \% \mathrm{~S}$ 와 $50.96 \mathrm{wt} \% \mathrm{Au}, 35.26 \mathrm{wt} \% \mathrm{Cu}, 6.04 \mathrm{wt} \%$ $\mathrm{Ni}, 7.32 \mathrm{wt} \% \mathrm{Zn}, 0.42 \mathrm{wt} \% \mathrm{~S}$ 가 검출되었다. $\mathrm{P} 3$ 는 합금 과정에서 남은 $\mathrm{Au}$-rich상으로 확인하였으며, 이러한 상의 존재는 표면의 불균일한 에칭으로 나타난 현상이다. 또한 $\mathrm{P} 4$ 는 $\mathrm{S}$ 가 상대적으로 높게 검출되어 이는 앞서 그림 2에 서 확인한 $\mathrm{NiS}$ 에 의한 것으로 판단하였다.

한편, $\mathrm{SDS} 0.1 \mathrm{~g} / \mathrm{L}$ 와 $0.2 \mathrm{~g} / \mathrm{L}$ 첨가하는 경우, $\mathrm{P} 5, \mathrm{P} 6$ 그리고 $\mathrm{P} 7$ 으로 표시한 부분의 결과에서 확인한 바와 같이, $\mathrm{EDS}$ 결과에서 $\mathrm{S}$ 가 검출되지 않았으며, 목표한 주조 조성 과 유사한 것을 확인하였다. 따라서 $\mathrm{SDS}$ 를 첨가한 스트리 핑 공정의 경우 $\mathrm{S}$ 가 검출되지 않아 $\mathrm{NiS}$ 형성이 없는 것 을 확인하였으며, 이는 $\mathrm{SDS}$ 가 첨가된 스트리핑을 통해 기 존에 알려진 금속황화물의 생성 없이 주조직후의 부동태막 을 성공적으로 제거할 수 있음을 의미한다.

그림 5 은 $\mathrm{SDS}$ 함량에 따른 $\mathrm{LSV}$ 분석 결과이다. 그래 프에 표시한 바와 같이 SDS 첨가량이 증가함에 따라 산 화전류밀도의 크기가 점차 감소하는 현상을 확인하였다.

$\mathrm{SDS}$ 를 첨가하지 않는 경우 $0.42 \mathrm{~V}$ 는 티오우레아가 formamidine disulfide(FD)로 산화되는 것을 나타낸다. 이 는 아래 식 (1)-(3)으로 나타낸 티오우레아의 연속반응에 의해 금이 용출되고 동시에 황화물이 형성되는 것으로 알 려져 있다 [13,20]. 이때 식 (1)은 티오우레아가 $\mathrm{FD}$ 로 산 화되는 반응, 식 (2)는 $\mathrm{FD}$ 가 산화제로 작용해 금을 용출 시키는 반응, 식 (3)은 $\mathrm{FD}$ 가 황화물로 분해되는 반응을 의미한다. 이때 생성된 황화물은 백색금 시료의 $\mathrm{Ni}$ 과 반응 하여 $\mathrm{NiS}$ 를 형성하며, 일단 형성된 치밀한 $\mathrm{NiS}$ 는 제거가 어려운 것으로 보고된 바 있다 [12].

$$
\begin{aligned}
& 2 \mathrm{CS}\left(\mathrm{NH}_{2}\right)_{2} \rightarrow \mathrm{FD}+2 \mathrm{H}^{+}+2 \mathrm{e}^{-} \\
& 2 \mathrm{Au}+\mathrm{FD}+4 \mathrm{CS}\left(\mathrm{NH}_{2}\right)_{2}+2 \mathrm{H}^{+} \rightarrow 2 \mathrm{Au}\left(\mathrm{CS}\left(\mathrm{NH}_{2}\right)_{2}\right)_{2}^{+} \\
& \mathrm{FD} \rightarrow \text { Sulfuric compounds }+\mathrm{CS}\left(\mathrm{NH}_{2}\right)_{2}
\end{aligned}
$$

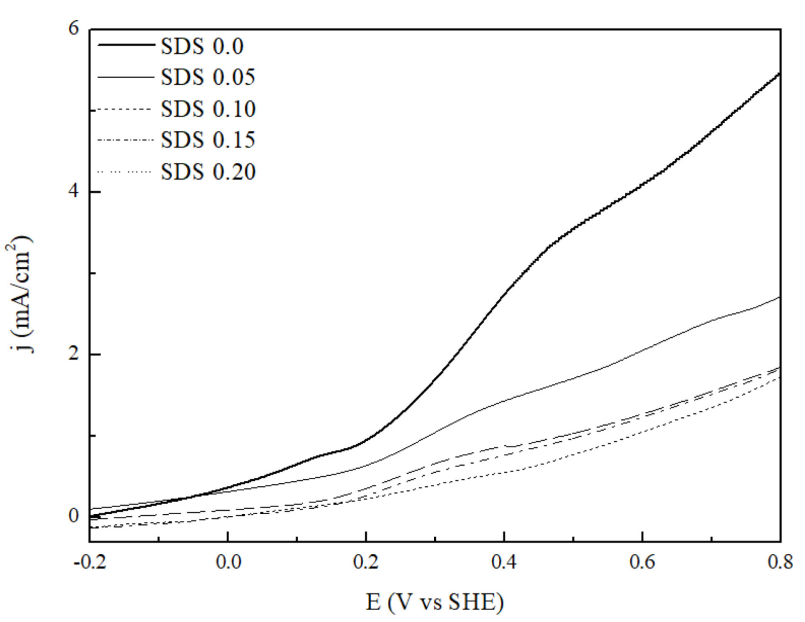

Fig. 5. LSV result of $14 \mathrm{~K}$ WG electrode according to SDS contents.

그러나 SDS가 첨가되면 식 (1) FD 형성반응이 억제되 며, 이에 따라 후속 식 (2)의 금 용출반응도 느려져 무게 감소율이 줄어드는 것으로 판단하였다. 식 (3) $\mathrm{FD}$ 의 자기 분해 반응도 느려져 황화물의 형성이 억제되며, 이는 $\mathrm{NiS}$ 형성이 없는 건전한 스트리핑이 가능함을 의미하였다.

\section{4. 결 론}

본 연구에서는 인베스트먼트 주조된 $\mathrm{Ni}$ 계-14 K 백색 금 합금에 대한 티오우레아 스트리핑 공정을 위해, SDS 계면 활성제, 티오우레아 착물제, 황화철 산화제로 구성된 스트 리핑 용액을 제안하였다. SDS를 첨가하지 않는 경우 주조 부동태막은 제거되지만 부산물로 표면 전체에 치밀한 $\mathrm{NiS}$ 가 형성되는 문제가 있었다. SDS를 첨가하면, 주조 부동 태막을 제거할 수 있었고, 티오우레아의 자기분해로 인한 금 용출과 황화물 형성이 억제되어, 스트리핑에 따른 무게 감소율도 저하시키고, $\mathrm{NiS}$ 의 생성도 효과적으로 억제하였 다. 따라서 제안된 티오우레아 스트리핑은 SDS $0.15 \mathrm{~g} / \mathrm{L}$ 이 상의 첨가에서 $\mathrm{Ni}$ 계 $-14 \mathrm{~K}$ 백색 금합금 스트리핑 공정에 적용 가능성을 확인하였다.

\section{REFERENCES}

1. L. Coentrao and D. Moura, Am. J. Emerg. Med. 29, 78 (2011).

2. M. E. Wadsworth, X. Zhu, J. S. Thompson, and C. J. Pereira, Hydrometallurgy 57, 1 (2012).

3. G. Senanayake, Miner. Eng. 17, 785 (2004).

4. M. Beghalha, Int. J. Miner. Proc. 82, 178 (2007). 
5. L. F. Kozin, V. A. Prokopenko, and A. K Bogdanova, Prot. Met. 41, 22 (2005).

6. S. Seisko, M. Lampinen, J. Aromaa, A. Laari, T. Koiranen, and M. Lundström, Miner. Eng. 115, 131 (2018).

7. M. I. Jeffrey, P. L. Breuer, and W. L. Choo, Metall. Mater. Trans. B 32, 979 (2001).

8. D. M. Muir and M. G. Aylmore, Miner. Process. Extr. Met. Trans. C 113, 2 (2004).

9. B. Xu, W. Kong, Q. Li, Y. Yang, T. Jiang, and X. Liu, Metals 7, 222 (2017).

10. J. Y. Li, X. L, Xu, and W. Q. Liu, Waste Manage. 32, 1209 (2012).

11. H. I. So, J. Lee, and Y. C. Cho, Korean J. Met. Mater. 56, 511 (2018).

12. J. C. Lin and J. J. Huarng, J. Appl. Electrochem. 24, 157 (1994).
13. U. S. Mohanty, B. C. Tripathy, S. C. Das, and V. N. Misra, Met. Mater Trans. B 36737 (2005).

14. D. Feng and J. S. J. Deventer, Miner. Eng. 24, 115 (2011).

15. A. Dutta and S.K. Dolui. Meter. Chem. Phys. 112, 448 (2008).

16. G. M. Ingo, C. Riccucci, and G. Chopzzino, J. Am. Ceram Soc. 84, 1839 (2001).

17. O. O. Balayeva, A. A. Azizov, M. B. Muradov, A. M. Maharramov, G. M. Eyvazova, R. M. Alosmanov, Z. Q. Mamiyev, and Z. A. Aghamaliyev, Mater. Res. Bull. 75, 155 (2016).

18. D. M. Soares, W. E. Gomes, and M. A. Tenan, Langmuir 23, 4383 (2007).

19. F. Burat, H. Basturkcu, and M. Ozer, Waste Manage. 89, 10 (2019).

20. J. Li and J. D. Miller, Hydrometallurgy 63, 215 (2002). 